\title{
SIMULASI TIGA DIMENSI POLA ARUS DAN DISTRIBUSI SEDIMEN DI PERAIRAN CILACAP SEBAGAI EVALUASI TERHADAP KONDISI DERMAGA
}

\author{
Danar Guruh Pratomo ${ }^{1}$, Nicolody Ofirla Eflal Froditus ${ }^{2}$, Cherie Bhekti Pribadi ${ }^{3}$ \\ 1,2,3 Departemen Teknik Geomatika, FTSLK-ITS, Kampus ITS Sukolilo, Surabaya, 60111, Indonesia \\ e-mail: ${ }^{2}$ nicolodyo@gmail.com
}

\begin{abstract}
Abstrak
Pemodelan distribusi arus di Perairan Cilacap, Indonesia sangat dipengaruhi oleh kedaan geografinya. Area ini berada di Selat Cilacap dan langsung berhadapan dengan Samudera India dengan karakteristik arus yang kuat. Model tiga dimensi yang telah dihasilkan, akan diketahui pola arus dan distribusi sedimen di perairan tersebut. Parameter yang digunakan dalam pemodelan ini termasuk hidro-oseanografi seperti pasang surut, river discharge, batimetri dan sedimen. Dengan river discharge yang digunakan berasal dari Sungai Donan dan Yasa. Dalam penelitian ini model arus dan sedimentasi akan dibentuk berdasarkan simulasi numerik dengan persamaan hidrodinamika. Berdasarkan hasil simulasi hidrodinamika, pada periode spring tide, kecepatan arus rata-rata dan maksimum adalah 0,6 m/s dan 0,8 m/s dengan ketebalan sedimen yang mengalami erosi sebesar 0,004 - 0,01 meter. Sedangkan, kondisi sedimentasi mengakibatkan terjadinya ketebalan sedimen mencapai 0,002-0,01 meter. Selama periode neap tide, kecepatan arus rata-rata yang terjadi sebesar $0,2 \mathrm{~m} / \mathrm{s}$ dan sedimen bergerak secara signifikan. Sehingga pada periode ini terjadi sedimentasi yang besar, yakni 0,002 - 0,01 meter. Dengan tipe sedimen yang dominan di perairan ini berupa pasir. Deposisi memberikan efek terhadap aktivitas pelayaran, terutama disekitar dermaga dengan peristiwa sedimentasi sebesar 165,571 mm/bulan.
\end{abstract}

Kata kunci: dermaga, erosi, kecepatan arus, perairan Cilacap, sedimen transport, sedimentasi,

\begin{abstract}
The water flow distribution in Cllacap's water is challenged by geographically. This area is a strait adjacent to Indian Ocean with a strong current flow characteristic. A three-dimensional model has been developed to understand the pattern of the flow and the sediment distribution in this water. The parameters used in modeling includes hydrooceanography, such as tidal, river discharge, bathymetry and sediment. River discharge that used came from Donan and Yasa River. In this research flow and sediments modelling will be formed using numerical simulation with hydrodynamics equations. Based on the hydrodynamic simulation, at the spring tide period, the average and maximum current magnitude are 0.6 and $0.8 \mathrm{~m} / \mathrm{s}$ respectively the thickness of sediment of erosion is $0.004-0.01$ meters. While, the effect sedimentation condition is that caused the formation of the sediment thickness is $0.002-0,01$ meters. During the neap tide, the average flow magnitude is $0.2 \mathrm{~m} / \mathrm{s}$ and sediment is moving significantly. Thus, in this period occurred the experience a great depositition, that is $0.002-0.01$ meters. The dominant type of sediment in this water is a type of sand. The sediment deposition in this area affects shipping lane, particularly in the around of jetty with the maximum depositition condition that is $165.571 \mathrm{~mm} /$ month.
\end{abstract}

Keywords: erosion, jetty, sedimentation, sediment transport, waters of Cilacap 


\section{PENDAHULUAN}

Kabupaten Cilacap secara geografis berada di tepi laut yang berhadapan dengan Samudera Hindia pada sisi Teluk Penyu dan dibatasi oleh Pulau Nusakambangan yang memanjang membujur barat-timur. Hal ini menyebabkan Perairan Cilacap memiliki pelabuhan samudera yang ideal dan menjadi perairan yang sibuk akan aktivitas lalu lintas kapal (Widhayanti, Ismanto, \& Yulianto, 2015). Salah satu objek penting dalam kegiatan operasional pelayaran adalah dermaga, mengingat dermaga merupakan suatu bangunan pelabuhan yang digunakan untuk merapat dan menambatkan kapal.

Misalnya saja, dermaga milik Pelabuhan Wijayapura (Kabupaten Cilacap) dan Pelabuhan Sodong (Pulau Nusakambangan), merupakan pelabuhan yang biasa digunakan sebagai sarana operasional Departemen Kehakiman dalam mobilisasi penjahat ke penjara Nusakambangan. Kedua dermaga merupakan dermaga penting yang menghubungkan Kabupaten Cilacap dengan Pulau Nusakambangan untuk dapat menyeberangi Selat Cilacap (BPS, 2017). Lokasi dermaga yang berada di selat dan muara sungai mengakibatkan rawan terhadap pengaruh sedimentasi, yang dikhawatirkan mempengaruhi kegiatan pendaratan kapal. Hal ini dikarenakan adanya pergerakan arus dan karakteristik fraksi sedimen yang ada di perairan tersebut. Mengingat kinerja pelabuhan sangat tergantung pada kedalaman alur pelayaran dan kolam labuhnya (Purnomo, Widiyanto, Pratiwi, \& Moe, 2015). Salah satu langkah untuk mengatasi pendangkalan dilakukan dengan proses pengerukan sedimen yang mengendap. Oleh karena itu, agar proses pengerukan berjalan efektif, perlu pengetahuan tentang fenomena hidrodinamika dan transpor sedimen dengan simulasi model numerik.

Pada penelitian ini, pendekatan yang dilakukan untuk mengetahui pola arus dan sedimen adalah melalui aplikasi model matematik/numerik dengan persamaan hidrodinamika. Kajian pemodelan numerik dalam penelitian ini diharapkan dapat dilakukan menggunakan perangkat lunak Delft3D sehingga pola arus dan pola sebaran sedimen dapat diketahui secara berkala dan kontinu. Dengan harapan dapat menganalisis dampak yang diberikan terhadap dermaga milik Pelabuhan Wijayapura dan Sodong.

\section{METODE}

\section{Lokasi Penelitian}

Lokasi penelitian ini adalah perairan Cilacap, Kabupaten Cilacap, Jawa Tengah yang terkhusus fokus pada perairan selat Cilacap yang menghubungkan Pelabuhan Wijayapura dengan Sodong. Secara geografis lokasi penelitian ini terletak pada koordinat $7^{\circ} 43^{\prime} 30^{\prime \prime}$ LS dan $108^{\circ} 59^{\prime} 18^{\prime \prime}$ BT sampai dengan $7^{\circ} 45^{\prime} 54^{\prime \prime}$ LS dan $109^{\circ} 3^{\prime} 42^{\prime \prime}$ BT, ditunjukkan dalam Gambar 1.

Sehingga sistem proyeksi UTM yang digunakan adalah zona 49S. Dengan satuan atau unit ukuran yang digunakan untuk menyatakan baik koordinat $(x, y)$, kedalaman (z), dan aspek lain adalah meter $(\mathrm{m})$.

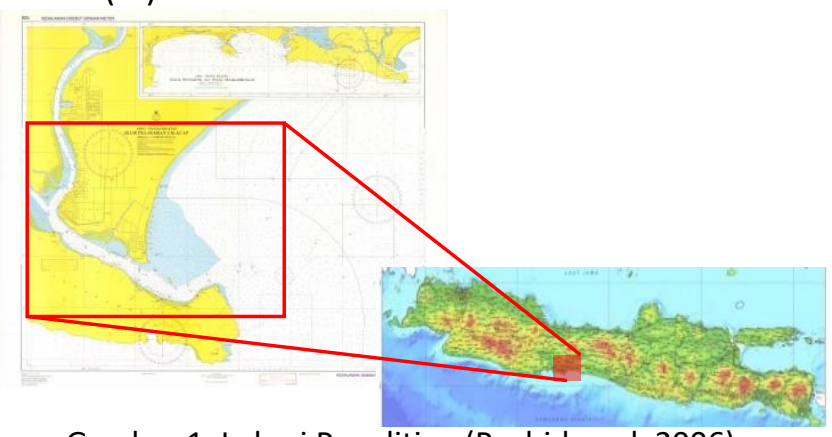

Gambar 1. Lokasi Penelitian (Pushidrosal, 2006)

\section{Data}

Adapun data yang digunakan dalam penelitian ini terbagi kedalam data spasial dan data hidrooseanografi. Data spasial merupakan data yang memiliki referensi geografis (sistem koordinat) yang mengacu pada bumi. Data spasial dalam penelitian ini terdiri dari: Peta Laut Alur Pelayaran Cilacap (Jawa-Pantai Selatan) Tahun 2006 dan Peta Rupa Bumi Indonesia Wilayah Cilacap-Nusakambangan Tahun 1999.

Sedangkan, data hidro-oseanografi merupakan data utama yang mempengaruhi terjadiya proses hidrodinamika laut. Data ini terdiri dari: data batimetri, data elevasi pasang surut, arus hasil ADCP, kecepatan dan arah angin, sampel sedimen dan data river discharge.

\section{Pengolahan Data}

Tahap awal pengolahan data dalam penelitian ini adalah melakukan rektifikasi dan digitasi terhadap 
peta raster Rupa Bumi Indonesia (RBI) CilacapNusakambangan dan Peta Laut Perairan Cilacap menggunakan software ArcGIS 10.3. Proses digitasi terhadap peta RBI akan menghasilkan data garis pantai yang memiliki referensi datum vertikal MSL. Sedangkan, proses digitasi terhadap peta laut akan memperoleh data spoth depth. Kedua data hasil digitasi merupakan data dalam format *.shp. Untuk dapat melanjutkan pada proses selanjutnya, setiap hasil akhir dalam proses pengolahan ini perlu dikonversi kedalam format file sesuai kebutuhan untuk proses selanjutnya.

Pembuatan model domain (mesh) diawali dengan mendefinisikan batas area model (close bounderies) yang diwakilkan oleh garis pantai dan kenampakan dermaga. Sehingga dengan adanya definisi batas ini wilayah daratan dan perairan dapat dibedakan. Tahapan berikutnya adalah proses building mesh, mesh dibentuk dengan menggabungkan data kedalaman serta model grid yang sebelumnya telah di desain menggunakan modul RGFGRID. Dalam penelitian ini grid yang dibuat merupakan tipe structured grid, dengan model grid berbentuk kotak.

Sedangkan, proses utama building mesh merupakan thap memberi nilai kedalaman pada tiap-tiap grid cell, melalui proses interpolasi di modul QUICKIN. Metode interpolasi yang digunakan adalah metode triangular interpolation, dengan sumber informasi kedalaman berasal dari data batimetri spot depth dan hasil survei menggunakan multibeam echosounder yang tersebar di Perairan Cilacap.

Data pengamatan pasang surut yang digunakan merupakan data observasi lapangan selama 29 piantan, dengan interval pengamatan setiap 1 jam. Pada penelitian ini dilakukan perhitungan nilai amplitudo dan fase 9 konstituen pasut, untuk mengetahui besarnya nilai datum vertikal Mean Sea Level (MSL) serta tipe pasang surut dengan formula Formzahl sebagai berikut:

$$
\mathrm{F}=\frac{\mathrm{AK} 1+\mathrm{AO} 1}{\mathrm{AM} 2+\mathrm{AS} 2}
$$

Dalam penelitian ini, input parameter utama penggerak arus merupakan data pasang surut dengan datum vertikal MSL sama dengan nol. Sehingga perlu adanya proses datum shift. Proses ini dilakukan dengan cara mengurangkan setiap bacaan pasang surut observasi terhadap nilai MSL hasil perhitungan sebelumnya.

Simulasi model dijalankan selama 29 piantan dari tanggal 12 Juli sampai dengan 9 Agustus 2017, dengan time frame yang terbagi menjadi 0,5 hari (spin up), 4,5 hari (warming up), dan 24 hari (simulasi). Langkah waktu (time step) yang digunakan sebesar 0,05 detik dengan mempertimbangkan syarat kestabilan CFL (Courant Friedich Lewy).

Pemodelan pada penelitian ini selain mendifinisikan close bounderies dilakukan juga pendefinisian open bounderies sebagai lokasi sumber pembangkit arus. Berdasarkan sumber penggerak arus, open bounderies terbagi kedalam 2 jenis. Jenis pertama adalah open bounderias dengan sumber penggerak arus berupa water level selama 29 hari. Sedangkan sumber penggerak kedua berasal dari debit sungai (river discharge) yang berasal dari Sungai Donan dan Yasa.

Selain parameter di atas, digunakan juga parameter angin dan fraksi sedimen. Dengan data angin berupa data kecepatan dan arah angin harian yang diperoleh dari BMKG. Sedangkan, dari hasil uji laboratorium 5 sampel sedimen, diketahui bahwa jenis sedimen pasir, yang tergolong kedalam sedimen yang bersifat non-kohesif. Dalam model ini asumsi fraksi pada semua sampel sedimen memiliki specific density sebesar $2650 \mathrm{~kg} / \mathrm{m}^{3}$. Dan nilai $d r y$ density sebesar $1600 \mathrm{~kg} / \mathrm{m}^{3}$, dengan ketebalan sedimen awal sebesar 0,5 meter. Set up pemodelan ditunjukkan pada Tabel 1.

Untuk mengetahui kualitas data hasil simulasi, perlu dilakukan proses validasi. Hal tersebut dilakukan terhadap data pasang surut dan arus hasil akuisisi lapangan terhadap hasil model. Perhitungan statistik yang digunakan dalam proses validasi data didapat dengan menghitung nilai RMSe (Root Mean Square Error) dan MAE (Mean Absolute Error) untuk mengetahui nilai dan tingkat kesalahan ukuran absolut hasil model yang menyimpang dari data observasi, dengan formula MAE sebagai berikut (Willmott \& Matsuura, 2005):

$$
\text { MAE }=\frac{1}{N} \sum_{i=1}^{n}\left|x_{m o d, i}-x_{o b s, i}\right|
$$

Selain itu dilakukan juga uji statistik menggunakan Root Mean Square Error (RMSe), 
dengan menggunakan formula berikut:

$$
\text { RMSe }=\sqrt{\frac{\sum_{i=1}^{n}\left(x_{\text {mod, } i}-x_{o b s, i}\right)^{2}}{n}}
$$

Jika kualitas data memiliki nilai RMSe dan MAE relatif kecil atau minimum dengan klasifikasi tingkat kesalahan kecil, dapat disimpulkan bahwa algoritma pengolahan data berjalan dengan baik dan benar. Sehingga model arus dan sedimen dapat digunakan untuk proses selanjutnya yakni proses analisis pola arus dan sedimen.

Tabel 1. Set Up Pemodelan Arus dan Sedimen

\begin{tabular}{ll}
\hline \multicolumn{1}{c}{ Deskripsi } & \multicolumn{1}{c}{ Nilai } \\
\hline Coriolis & -7 derajat \\
Number of layer & 1 lapis \\
Processes & Constituents : \\
& Sedimen \\
& Physical : Angin \\
Initial conditions & Uniform values \\
Initial surface level & 0 meter \\
Boundary & Muka air (pasut) dan \\
& river discharge \\
Morphology & Update kedalaman \\
Numerical parameters & Sel ditengah grid \\
Roughness & Chezy \\
Interpolation type wind & Linear \\
Wind drag coefficients & Default \\
Initial concentration & 0 kg/m ${ }^{3}$ \\
sediments & \\
Sediment & 5 sampel sedimen \\
& pasir \\
\hline
\end{tabular}

Sebagai penunjang untuk mengukur (kuat, lemah, atau tidak ada) hubungan antar variabel (observasi dan model) maka dilakukan perhitungan koefisien korelasi (R) (Hasan, 2009).

\section{HASIL DAN PEMBAHASAN}

\section{Model Domain (Mesh)}

Salah satu data penting dalam pembuatan mesh adalah grid, dibuat sedemikian rupa hingga mewakili area studi. Dalam penelitian ini area yang ditinjau adalah area laut dan sungai, sehingga model grid dibuat semakin kecil ketika berada di area sungai. Gambar 2 merupakan model grid dalam penelitian ini.

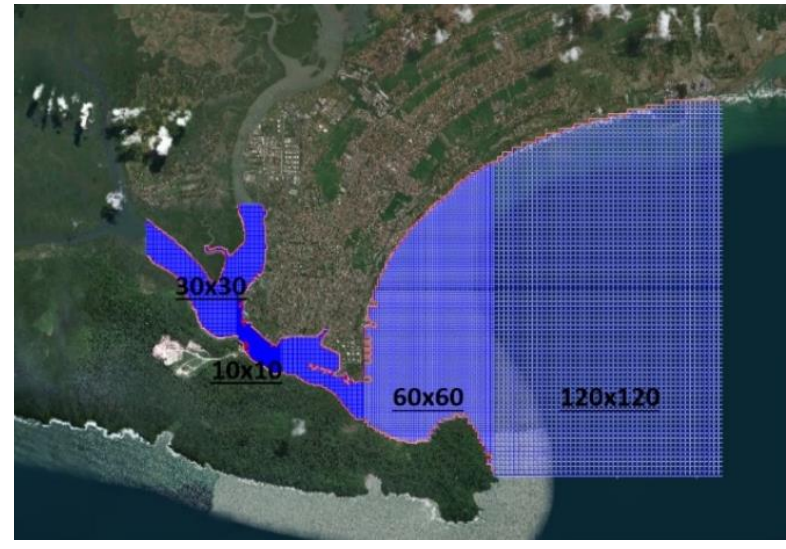

Gambar 2. Model Grid

Model grid dibagi kedalam beberapa bagian yang dibagi atas dasar ukuran. Dibuat sedemikian rupa, untuk dapat mewakili are studi. Sehingga, dihasilkan grid dengan ukuran 120×120, 60×60, $30 \times 30$, dan $10 \times 10$ dalam satuan meter.

Hasil penggabungan data kedalaman dan model grid melalui proses interpolasi dengan metode triangular interpolation. Menghasilkan model domain (mesh) sebagai batas area model seperti pada Gambar 3 sebagai berikut.

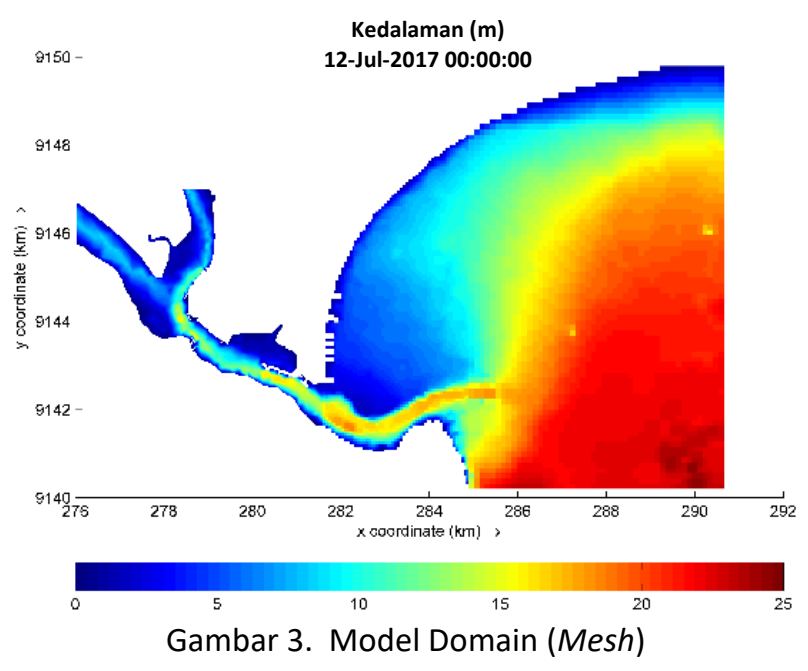

\section{Pasang Surut}

Data pasang surut observasi merupakan data pengamatan langsung di lapangan pada lokasi stasiun pasut yang berada di selat Cilacap dengan lokasi koordinat pada $7^{\circ} 44^{\prime} 26^{\prime \prime}$ LS dan $108^{\circ} 59^{\prime} 57^{\prime \prime}$ BT. Data pengamatan tersebut, digunakan untuk mendapatkan nilai muka air laut rata-rata (SO) dan nilai amplitudo $(A)$ serta beda fase $\left(g^{\circ}\right) 9$ konstituen harmonik perairan Cilacap. Kemudian nilai-nilai tersebut digunakan dalam perhitungan untuk memperoleh beberapa nilai referensi tinggi. 
Metode perhitungan konstituen harmonik menggunakan metode perataan kuadrat terkecil (least square).

Tabel 2. Nilai Referensi Tinggi

\begin{tabular}{lc}
\hline \multicolumn{1}{c}{ Referensi Tinggi } & Tinggi $(\mathrm{m})$ \\
\hline MSL & 1,860 \\
LWL & 1,082 \\
HWL & 2,638 \\
\hline
\end{tabular}

Nilai referensi tinggi pada Tabel 2 tersebut digunakan untuk melakukan proses datum shift. Sehingga akan diperoleh data pasang surut observasi dengan referensi tinggi MSL. Selain itu, dengan perhitungan menggunakan persamaan Formzahl, dihasilkan nilai bilangan Formzahl (F) sama dengan 0,356. Artinya tipe pasang surut pada perairan Cilacap memiliki tipe Campuran Dominan Semidiurnal (mixed semidiurnal tide). Maka, dalam satu hari akan terjadi dua kali air pasang dan air surut, dengan tinggi dan periode yang berbeda.

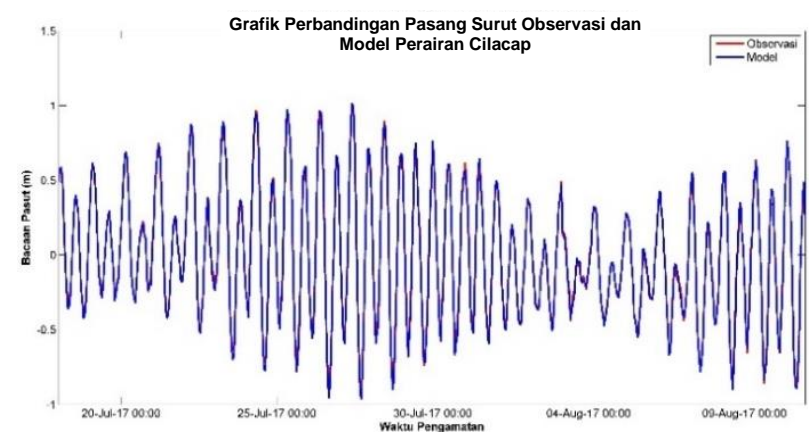

Gambar 4. Grafik Perbandingan Pasang Surut

Observasi dan Hasil Model

Pada Gambar 4 menunjukkan grafik perbandingan data pasang surut observasi dengan model. Melalui data hasil pemodelan pada tanggal 17 Juli sampai dengan 09 Agustus 2017 tersebut, diperoleh nilai Root Mean Square Error (RMSe) dan Mean Absolute Error (MAE) sebesar 0,030meter dan 0,024-meter. Hal ini menunjukkan bahwa nilai MAE yang didapatkan relatif kecil dengan tingkat kesalahan tergolong dalam klasifikasi kesalahan kecil (Khotimah, 2012). Sedangkan, perhitungan koefisien korelasi kedua data menghasilkan nilai $R$ sebesar 0,998. Hal ini menunjukkan bahwa kedua variabel berkorelasi positif dan memiliki keeratan hubungan sangat tinggi (Hasan, 2009).

Dari hasil uji statistik RMSe dan MAE disimpulkan bahwa algoritma pengolahan data berjalan dengan baik dan benar. Sehingga hasil simulasi model arus dan sedimen dapat digunakan untuk proses selanjutnya.

\section{Pemodelan Arus}

Pola arus hasil simulasi merupakan pola arus yang terdiri dari nilai kecepatan dan arah gerak arus. Besarnya nilai kecepatan arus ditunjukkan oleh gradasi warna biru dan merah dengan nilai kecepatan arus yang dihasilkan merupakan kecepatan arus pada kedalaman rata-rata. Kecepatan arus ini diklasifikasi sesuai skala bar. Sedangkan, vektor menunjukkan variasi arah gerak arus.

Untuk mempermudah dalam proses analisis, maka proses analisis pola arus akan dibagi kedalam 2 periode. Kedua periode tersebut adalah periode spring dan neap, yang masing-masing periode juga akan dibahas pada kondisi terjadinya pasang dan surut.

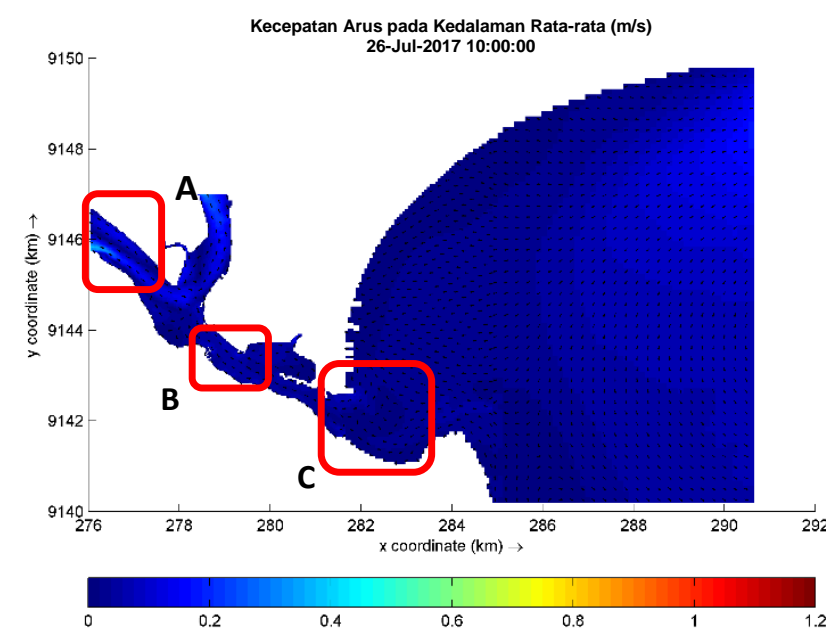

Gambar 5. Pola Arus Periode Spring Pasang Purnama

Pada Gambar 5, menunjukkan pola arus pada kondisi pasang purnama yang terjadi pada tanggal 26 Juli 2017 pukul 10.00 WIB pada timestep 1385. Kecepatan arus pada kondisi ini berkisar antara 0 sampai dengan 0,6 m/s, dengan kecepatan maksimum berada di Selat Cilacap seperti yang ditunjuk oleh area A. Vektor arus yang terbentuk pada kondisi ini menunjukkan bahwa arus bergerak dari laut ke wilayah pesisir Teluk Penyu dan bergerak ke arah laut atau ke arah Timur di wilayah Selat Cilacap. Sehingga, terjadi perpecahan arah arus, seperti yang ditunjuk oleh lokasi C. Hal ini dikarenakan terjadi pertemuan 2 arus dengan sumber penggerak yang berbeda (pasang surut dan river discharge). Bentuk dermaga tipe Jetty pada 
lokasi B, menyebabkan adanya pergerakan arus pada wilayah selat terhalang oleh dermaga. Sehingga arah arus yang dominan mengarah ke Timur, namun terdapat arah vektor yang kembali ke arah Barat. Dengan kecepatan arus antara 0,1 sampai dengan $0,3 \mathrm{~m} / \mathrm{s}$.

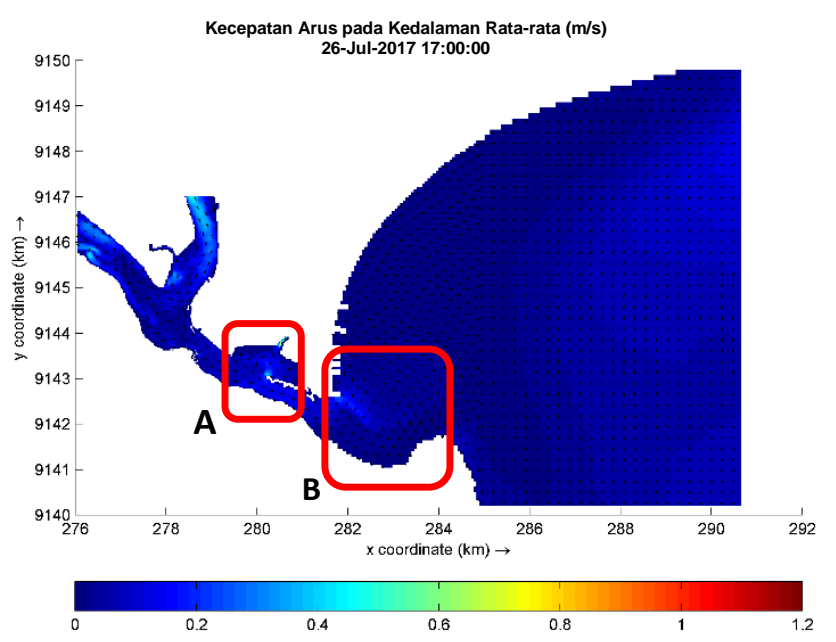

Gambar 6. Pola Arus Periode Spring Surut Purnama

Selanjutnya pada Gambar 6, menunjukkan pola arus pada kondisi surut purnama yang terjadi pada tanggal 26 Juli 2017 pukul 17.00 WIB, pada timestep ke 1413. Pola arus pada kondisi ini mengalami peningkatan nilai kecepatan arus. Dengan arus berkisar 0 sampai dengan $0,8 \mathrm{~m} / \mathrm{s}$, dan arus terbesar berada di lokasi $A$, yaitu arus yang berasal dari debit sungai Yasa. Yang membedakan pola arus pada kondisi surut purnama ini, terlihat bahwa arah arus di wilayah pesisir berlawanan dengan arah arus pada kondisi pasang purnama. Selain itu, terdapat peristiwa yang menarik di lokasi B, vektor arah arus berbelok ke Utara menuju ke dermaga yang ada di pesisir. Kondisi morfologi daratan Pulau Nusakambangan yang menjorok ke Utara, menutup sebagian mulut muara menjadi penyebab peristiwa ini.

Kemudian, akan dibahas mengenai pola arus yang terjadi pada periode neap. Dimana pada periode ini, nilai kecepatan arus relatif lebih kecil dibandingkan dengan pada periode spring. Tanggal 5 Agustus 2017 pukul 01.00 WIB merupakan waktu dimana terjadi surut perbani, sedangkan kondisi pasang perbani terjadi pada pukul 19.00 WIB.

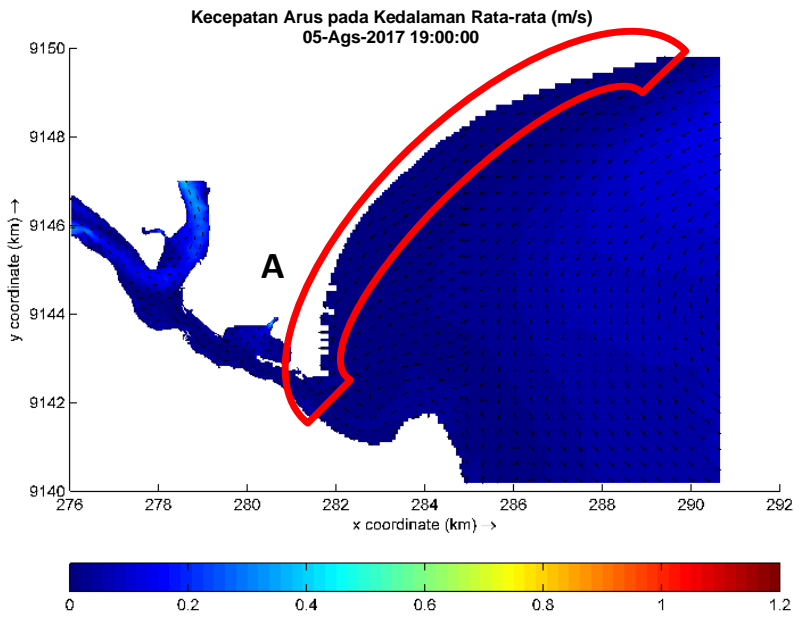

(a)

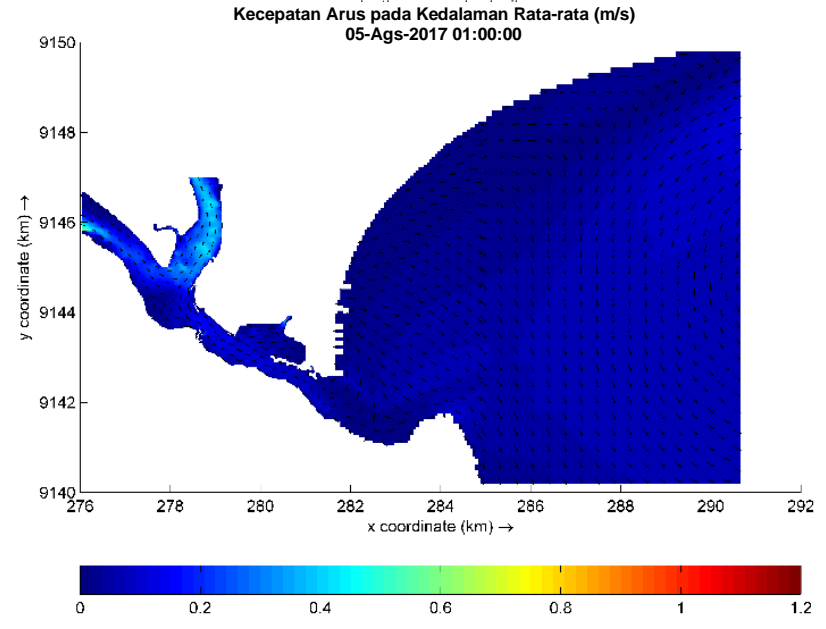

(b)

Gambar. 7. Pola Arus Periode Neap (a) Pasang Perbani (b) Surut Perbani

Pada Gambar 7a, menunjukkan pola arus pada kondisi pasang perbani, dengan kecepatan tertinggi sebesar $0,5 \mathrm{~m} / \mathrm{s}$. Jika melihat pola arah arus yang terbentuk pada simulasi model, arah arus yang ditunjukkan pada lokasi A. Pada lokasi tersebut terjadi longshore current atau arus yang sejajar pantai, bergerak menyusuri pantai disepanjang Teluk Penyu. Arah pergerakan arus diwilayah tersebut bergerak sejajar pantai ke arah Selatan.

Kemudian, pada Gambar 7b menunjukkan pola arus pada kondisi surut perbani. Dibandingkan dengan kecepatan arus pada kondisi pasang perbani, besar kecepatan pada kondisi ini mengalami peningkatan. Besar kecepatan maksimum pada kondisi ini hanya mencapai 0,6 $\mathrm{m} / \mathrm{s}$, yang terjadi di sungai Donan. Peristiwa longshore current juga terjadi pada kondisi ini, dengan arah arus bergerak sejajar pantai ke arah Utara. Longshore current pada perairan Cilacap terjadi karena adanya fenomena wave break yang 
akan membentuk arus baru dengan besar sudut tertentu sejajar dengan pantai.

Proses validasi juga dilakukan terhadap data arus observasi dan model dengan mengambil sampel data pada lokasi yang sama, yakni pada koordinat $7^{\circ} 44^{\prime} 38,22^{\prime \prime}$ LS dan $108^{\circ} 59^{\prime} 57,37^{\prime \prime}$ BT. Hasil perhitungan diperoleh besar nilai RMSe dan MAE sebesar $0,155 \mathrm{~m} / \mathrm{s}$ dan $0,121 \mathrm{~m} / \mathrm{s}$, yang berarti data hasil simulasi memiliki tingkat kesalahan tergolong kecil. Namun dari nilai koefisien korelasi yang dihasilkan, kedua data arus tidak saling berhubungan.

\section{Pemodelan Sedimen}

Analisis pola sebaran sedimen pada penelitian ini akan dianalisis pada 2 periode yakni periode spring dan neap. Analisis dilakukan terhadap kondisi total erosi/sedimentasi yang terjadi diperairan Cilacap. Besar nilai total erosi/sedimentasi akan ditampilkan kedalam gambar yang akan memberikan informasi besar ketebalan erosi/sedimentasi yang disajikan kedalam gradasi warna. Besar nilai negative (-) dan positif $(+)$ secara berurutan mewakili terjadinya erosi dan sedimentasi. Sedangkan arah persebaran sedimen ditunjukkan oleh arah vektor. Pada Gambar 8 (periode spring) dan Gambar 9 (period neap) akan ditunjukkan pola sebaran sedimen yang diwakilkan oleh total erosi/sedimentasi serta arah persebaran sedimen di Perairan Cilacap.

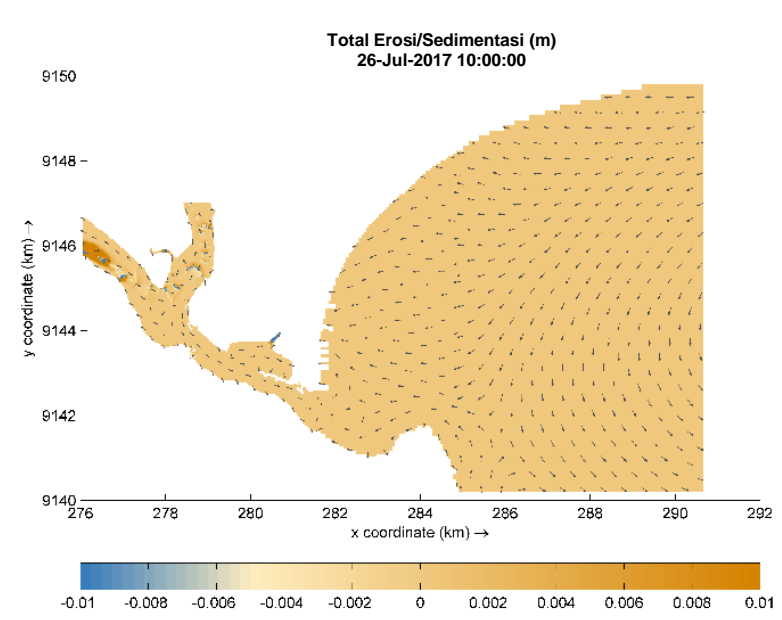

(a)

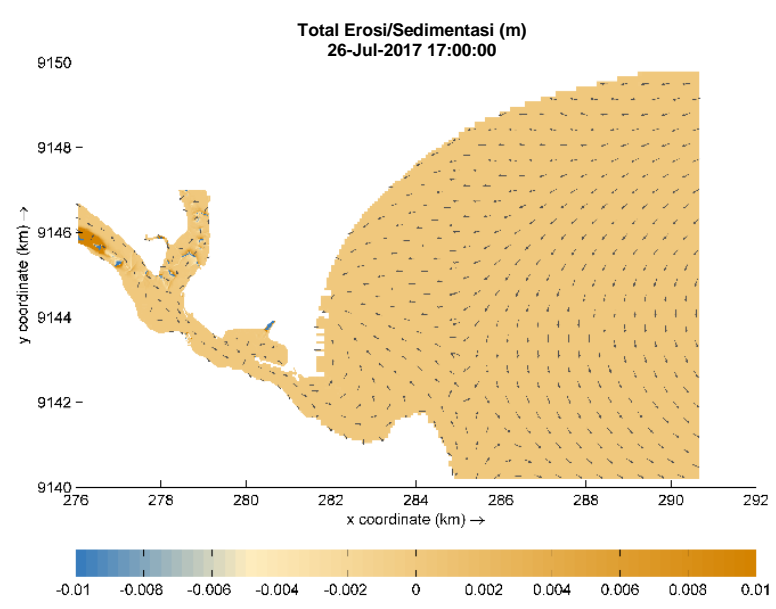

(b)

Gambar 8. Total Erosi/Sedimentasi Periode Spring (a) Pasang Purnama (b) Surut Purnama

Melalui total erosi/sedimentasi tersebut dapat diketahui bahwa pola sebaran sedimen pada periode spring dominan terjadi diarea sungai dan Selat Cilacap. Dengan besar nilai erosi yang terjadi di daerah tersebut memiliki ketebalan sedimen antara 0,004 s.d. lebih dari 0,01-meter dan nilai sedimentasi sebesar 0,002 s.d. lebih dari 0,01 meter. Pada kondisi pasang purnama, pergerakan sedimen disetiap mulut sungai, memiliki arah menuju ke sungai. Sedangkan pada kondisi surut purnama, arah sedimen berasal dari sungai bergerak keluar dari mulut sungai.

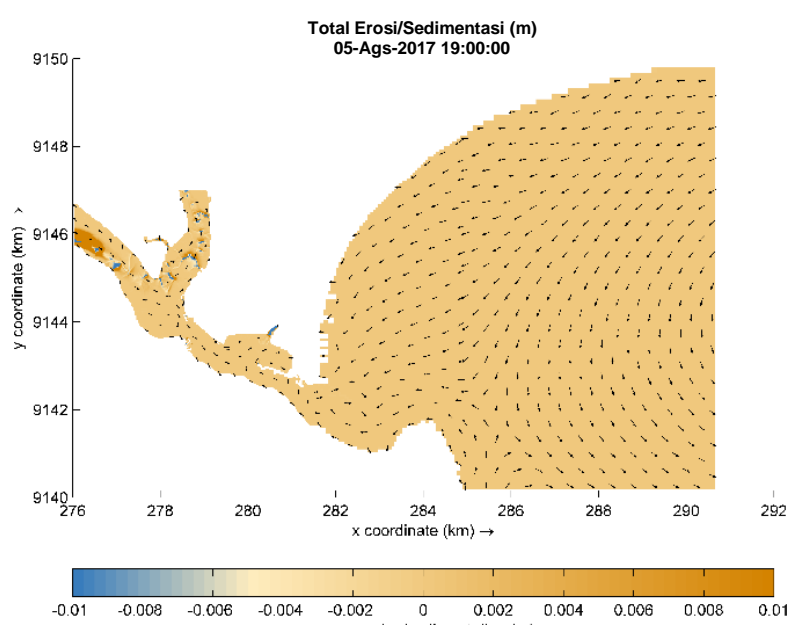

(a) Total Erosi/Sedimentasi $(\mathrm{m})$
05-Ags-2017 01:00:00 


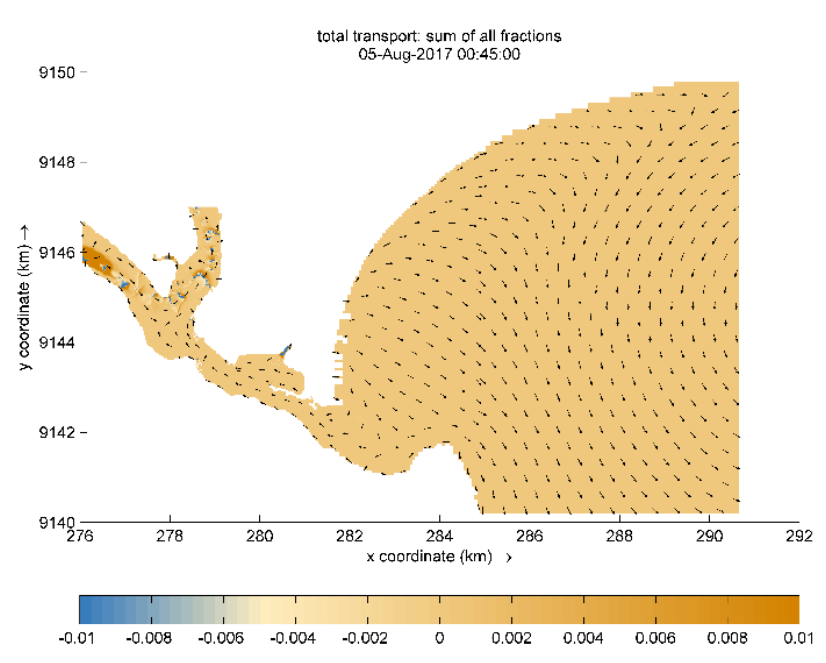

(b)

Gambar 9. Total Erosi/Sedimentasi Periode Neap (a) Pasang Perbani (b) Surut Perbani

Pada periode neap, peristiwa erosi di sekitar area sungai dan Selat Cilacap memiliki besar nilai dan luas erosi/sedimentasi lebih besar dibanding pada periode spring tide. Terlihat bahwa di area tersebut gradasi warna biru tua hingga ke warna putih lebih semakin meluas. Dengan nilai erosi di daerah tersebut memiliki ketebalan sedimen antara 0,005 s.d. lebih dari 0,01 meter. Sedangkan, ketebalan sedimen yang mengalami sedimentasi sebesar 0,002 s.d. lebih dari 0,01 meter. Dengan gerak arus pada periode ini, memiliki arah yang sama dengan periode spring.

Meninjau secara keseluruhan area model pada dua periode, kondisi erosi/sedimentasi banyak terjadi diwilayah muara sungai, Selat Cilacap dan sekitar dermaga. Selain itu jika diperhatikan dari periode spring ke periode neap, terlihat bahwa area erosi/sedimentasi mengalami perbedaan luas area dan besar nilai erosi/sedimentasi yang semakin besar dan meluas.

\section{Evaluasi Dermaga}

Berdasarkan hasil simulasi di wilayah dermaga dihasilkan kondisi aktivitas gerak sedimen. Dapat dilihat pada kondisi total erosi/sedimentasi seperti pada Gambar 10 yang memberikan informasi pergerakan material sedimen di wilayah tersebut.

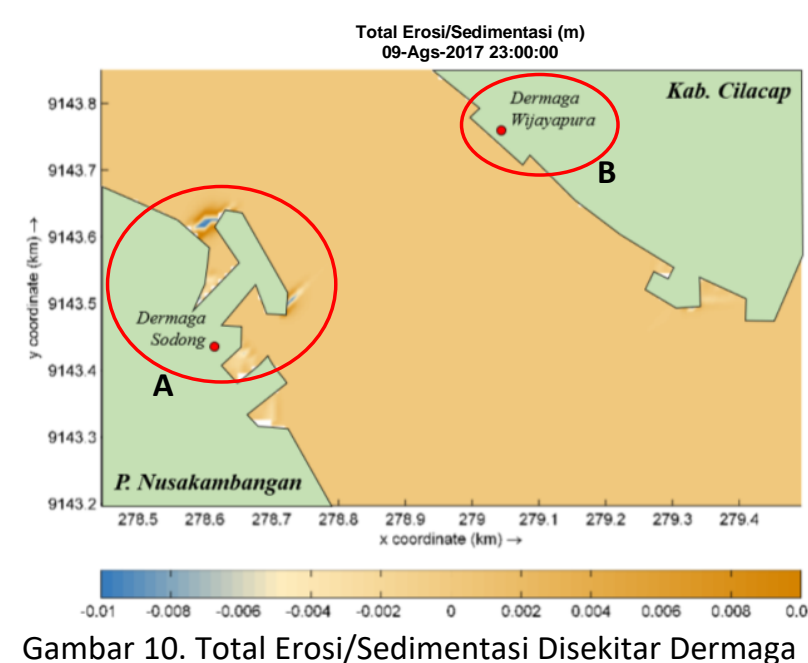

Pada lokasi A yang merupakan lokasi dermaga Sodong di Pulau Nusakambangan, terlihat di lokasi ini terjadi aktivitas erosi/sedimentasi. Kemudian, pada lokasi B yang menunjukkan lokasi dermaga Wijayapura, dimana pada wilayah ini tidak terjadi erosi/sedimentasi. Perbedaan bentuk tipe dan bentuk dari kedua dermaga, menyebabkan perbedaan aktivitas erosi/sedimentasi yang terjadi. Tipe dermaga Jetty merupakan dermaga yang menjorok ke perairan, hal ini yang menjadi salah satu penyebab terjadinya aktivitas erosi/sedimentasi di dermaga Sodong.

Aktivitas erosi/sedimentasi akan menyebabkan perubahan kedalaman pada area dermaga. Monitoring perubahan kedalaman akan dilakukan dan terfokus pada area dermaga Wijayapura dan Sodong, dimana perubahan kedalaman pada masing-masing waktu pengamatan ditunjuk oleh gradasi warna kedalaman area Dermaga seperti pada Gambar 11, sebagai berikut.

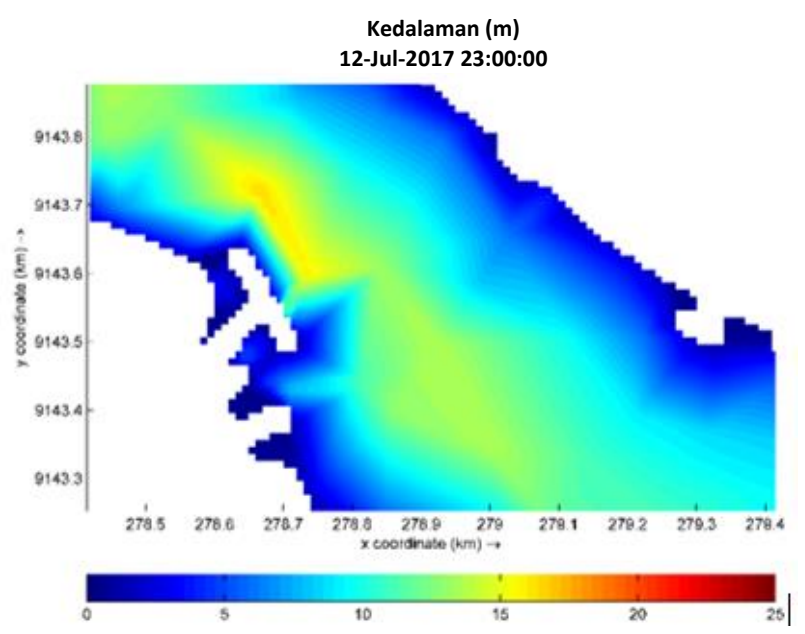

(a)

Kedalaman (m)

26-Jul-2017 23:00:00 


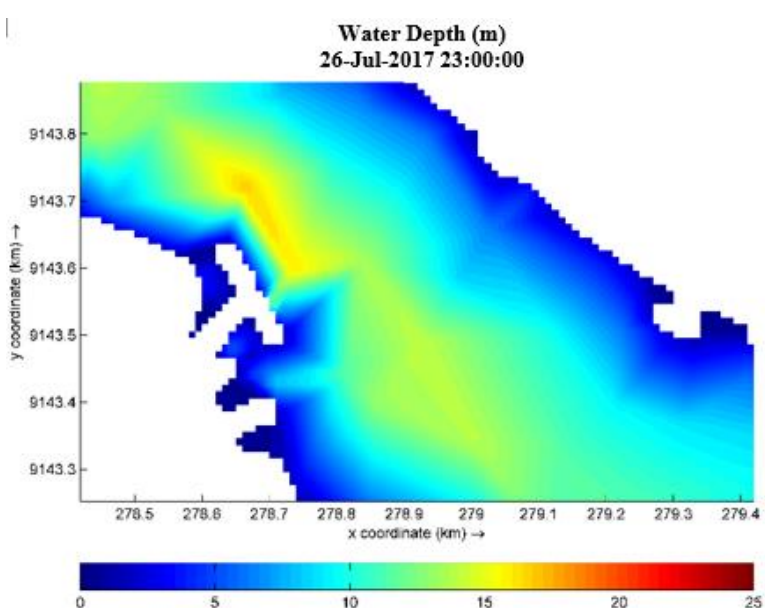

(b)

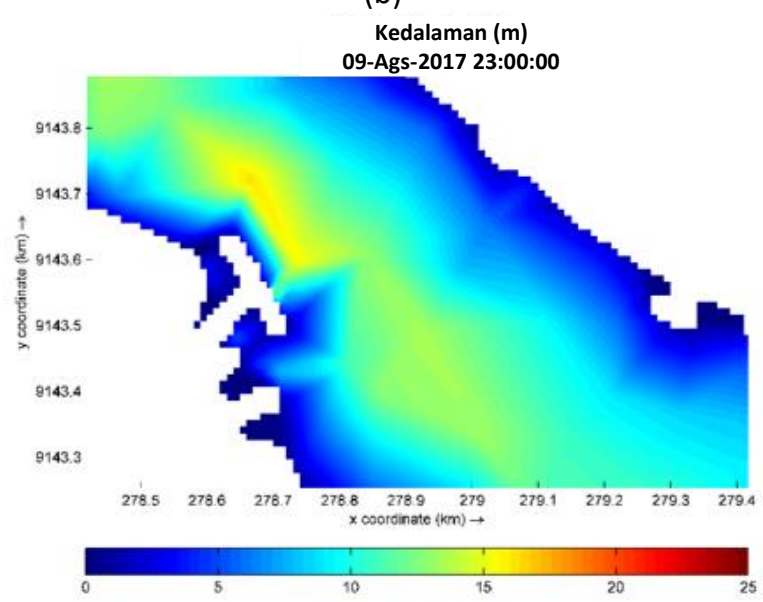

(c)

Gambar 11. Peribahan Kedalaman pada Kondisi (a) Awal, (b) Tengah, dan (c) Akhir Simulasi

Ketiga gambar memiliki perbedaan pada waktu pengamatan observasi perubahan kedalaman secara temporal. Pada gambar $11 a, b$ dan c terlihat perubahan kedalaman pada kondisi awal simulasi, tenga simulasi, dan akhir simulasi. Untuk mempermudah dalam melihat nilai perubahan kedalaman akibat adanya aktivitas sedimen, diambil beberapa titik pengamatan secara random yang lokasinya tersebar disekitar Dermaga Wijayapura dan Dermaga Sodong. Lokasi nilai perubahan kedalaman ditunjukkan oleh Gambar 12 sebagai berikut.

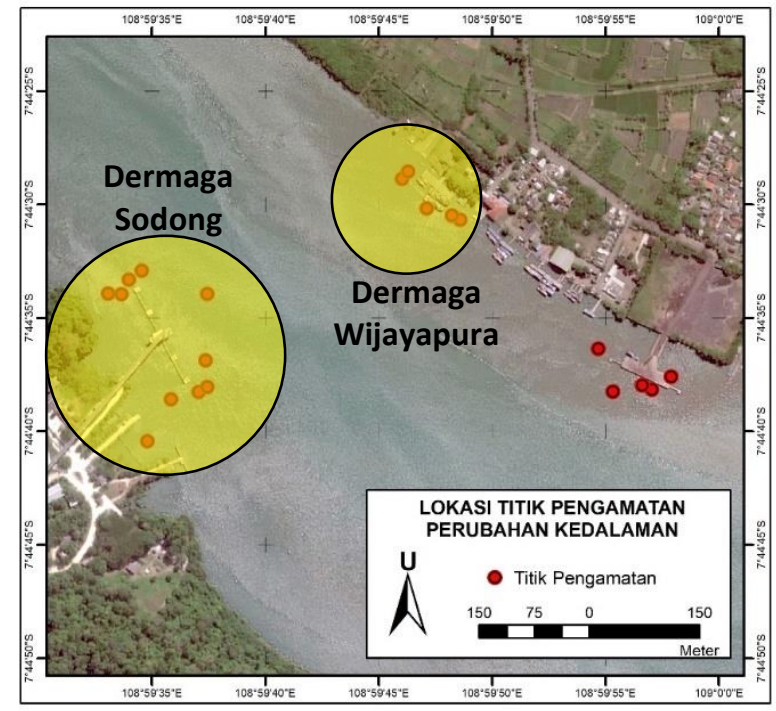

Gambar 12. Lokasi Titik Pengamatan Perubahan Kedalaman

Dengan nilai erosi/sedimentasi yang terjadi pada masing-masing titik pengamatan disekitar dermaga tersaji dalam Tabel 3.

Tabel 3. Nilai Perubahan Kedalaman

\begin{tabular}{ccccc}
\hline \multirow{2}{*}{ Dermaga } & Nama & \multicolumn{3}{c}{ Perubahan Kedalaman (mm) } \\
\cline { 2 - 5 } Sodong & Poin & Awal & Tengah & Akhir \\
\hline & B & 0,001 & 0,002 & 0,003 \\
& C & 0,149 & $-0,100$ & $-2,316$ \\
& D & $-4,781$ & $-11,480$ & $-12,879$ \\
& E & $-1,346$ & $-1,366$ & $-1,727$ \\
& F & 0,001 & 0,002 & 0,003 \\
& G & 3,217 & 5,010 & 10,656 \\
& H & 5,446 & 29,414 & 128,120 \\
& I & 1,926 & 3,251 & 6,272 \\
& J & 4,585 & 10,180 & 19,818 \\
& K & 0,000 & 0,000 & 0,000 \\
& L & 0,000 & 0,000 & 0,000 \\
& M & 0,000 & 0,000 & 0,000 \\
& N & 0,000 & 0,000 & 0,000 \\
& O & 0,000 & 0,000 & 0,000 \\
\hline
\end{tabular}

*Catatan: (-) adalah erosi dan (+) adalah sedimentasi

Dari Tabel 3 dapat diketahui bahwa aktivitas erosi/sedimentasi terjadi disekitar Dermaga Sodong dan tidak terjadi disekitar Dermaga Wijayapura. Dari 10 titik sampel di dekat Dermaga Sodong, 7 diantaranya mengalami sedimentasi, dengan perubahan kedalaman terbesar adalah 128,120 mm dalam 1 bulan. Dari beberapa sampel dapat diketahui bahwa total erosi/sedimentasi pada masing-masing dermaga ditunjukkan pada Tabel 4. 
Tabel 4. Total Erosi/Sedimentasi

\begin{tabular}{ccc}
\hline Dermaga & $\begin{array}{c}\text { Cum. Erosi } \\
(\mathrm{mm} / \mathrm{bln})\end{array}$ & $\begin{array}{c}\text { Cum. Sedimentasi } \\
(\mathrm{mm} / \mathrm{bln})\end{array}$ \\
\hline Sodong & $-16,921$ & 165,571 \\
Wijayapura & 0,000 & 0,000 \\
\hline
\end{tabular}

Perbedaan bentuk dan tipe dermaga, menjadikan salah satu factor perbedaan besarnya aktivitas erosi/sedimentasi di kedua dermaga. Sehingga, perlu adanya monitoring dan aktivitas pengerukan sedimen secara periode dan kontinu. Jika hal ini tidak dilakukan, dapat mengakibatkan aktivitas pelayaran di Dermaga Sodong terganggu, yakni terjadinya pendangkalan.

\section{KESIMPULAN}

Pola arus pada periode spring dan neap mengalami perbedaan baik pada arah dan kecepatan. Kecepatan maksimum arus pada perairan Cilacap di kondisi adalah $0,8 \mathrm{~m} / \mathrm{s}$ pada kondisi surut purnama (spring tide). Dengan kondisi pergerakan arah arus mengikuti periode pasang surut yang terjadi di perairan Cilacap. Sedangkan pola distribusi sedimen yang terjadi di Perairan Cilacap mengakibatkan adanya aktivitas erosi/sedimentasi, dengan aktivitas terbesar terjadi di daerah sungai dan Selat Cilacap. Kondisi deposisi terbesar mengakibatkan adanya penebalan sedimen antara 0,002 sampai dengan lebih dari 0,01-meter yang terjadi setelah 1 bulan simulasi. Melihat pola distribusi sedimen di sekitar dermaga memberikan efek terhadap Dermaga Sodong, yakni terjadinya pendangkalan. Perubahan kedalaman maksimum sebesar $128,120 \mathrm{~mm}$ dan total deposisi/sedimentasi sebesar 165,710 mm/bulan di sekitar Dermaga Sodong. Sehingga, perlu dilakukan kegiatan monitoring dan aktivitas pengerukan sedimen secara berkala.

\section{UCAPAN TERIMA KASIH}

Penulis mengucapkan terimakasih kepada Badan Metereologi, Klimatologi, dan Geofisika (BMKG), Badan Informasi Geospasial (BIG), dan Pusat Hidrografi dan Oseanografi TNI AL (Pushidrosal) yang telah menyediakan data serta bimbingannya selama penelitian ini berlangsung.

\section{DAFTAR PUSTAKA}

BPS Cilacap. (2017). Kabupaten Cilacap Dalam Angka 2017. Cilacap: BPS Kabupaten Cilacap.

Hasan, I. (2009). Analisis Data Penelitian dengan Statistika. Jakarta: Bumi Aksara.

Khotimah, Mia Khusnul. (2012). Validasi Tinggi Gelombang Signifikan Model Gelombang Windwave-5 dengan Menggunakan Hasil Pengamatan Satelit Altimetri Multimisi. Jakarta: Universitas Indonesia.

Purnomo, S. N., Widiyanto, W., Pratiwi, T. P., \& Moe, I. R. (2015). Analisis Sedimentasi di Pelabuhan Pendaratan Ikan (PPI) Logending. Dinamika Rekayasa, 11(1 Februari), 29-37.

Widhayanti, A., Ismanto, A., \& Yulianto, B. (2015). Sebaran Tumpahan Minyak Dengan Pendekatan Model Hidrodinamika dan Spill Analysis di Perairan Cilacap, Jawa Tengah. Jurnal Oseanografi Volume 4 Nomor 4, 4, 641-650.

Willmott, C. J., \& Matsuura, K. (2005). Advantages of the mean absolute error (MAE) over the root mean square error (RMSE) in assessing average model performance. Climate Research, 30(1), 79-82. https://doi.org/10.3354/cr030079. 